\title{
Multiple Yellow-Brown Papules on the Penis
}

Yeong Ho Kim, MD; Chul Hwan Bang, MD; Young Min Park, MD, PhD; Jun Young Lee, MD, PhD; Ji Hyun Lee, MD, PhD

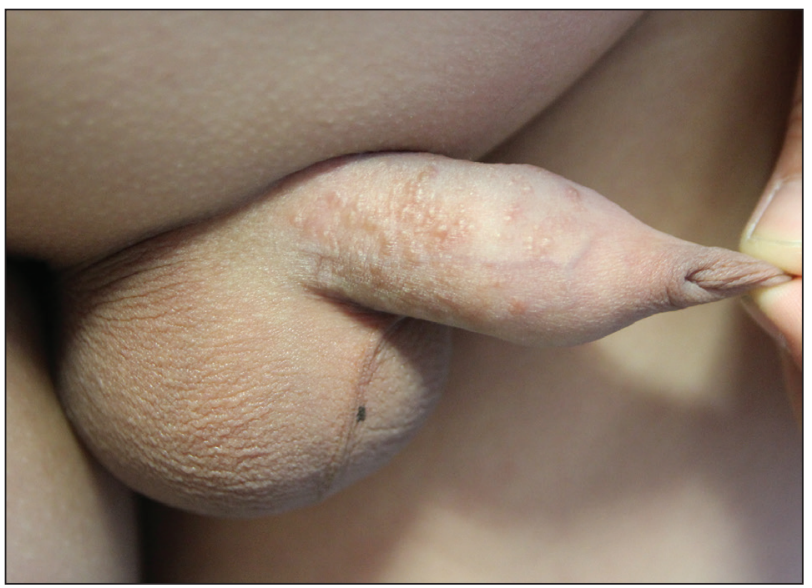

A 12-year-old boy presented with multiple asymptomatic, 0.1-cm, yellow-brown papules on the penile shaft of several years' duration. The lesions appeared suddenly. The patient had no history of trauma, injection, or an underlying disorder.

\section{WHAT'S YOUR DIAGNOSIS?}
a. eruptive syringoma
b. lichen nitidus
c. milia
d. molluscum contagiosum
e. verruca plana 


\section{THE DIAGNOSIS: Eruptive Syringoma}

A punch biopsy of a lesion on the penis was performed. Histopathologic examination revealed many tadpole-shaped cords of epithelial cells and small ducts in the dermis (Figure). Based on clinical and histopathological findings, a diagnosis of eruptive syringoma was made. The patient declined treatment.

Syringomas are common benign eccrine neoplasms. They present clinically as small flesh-colored to brownish papules symmetrically distributed on the face, neck, trunk, pubic area, arms, and legs. ${ }^{1-3}$ Classic syringoma occurs more frequently in young adult women. ${ }^{1}$ Eruptive syringoma is a rare variant, and the age of onset ranges from 3 to 50 years. ${ }^{1-13}$ Eruptive syringoma is the term for multiple lesions that occur synchronously in any part of the body. ${ }^{1,4,13}$ The term eruptive is not the opposite of localized and refers to the time of onset of the lesion. There may be both a generalized eruptive syringoma or a localized eruptive syringoma depending on the distribution of the lesions. ${ }^{1}$ The most common site for syringoma occurrence is the eyelid; penile syringoma is extremely rare. Several cases of penile syringoma have been reported, but eruptive penile syringoma is rare. $3,5-10,12,13$

Histopathology is essential for the diagnosis of syringoma. Hematoxylin and eosin stain shows multiple small cystic ducts and epithelial cell nests in the dermis. Ductal structures sometimes appear tadpolelike or comma shaped depending on the section. ${ }^{1,2,7,12}$

The clinical differential diagnosis of syringoma includes sebaceous hyperplasia, yerruca plana, molluscum contagiosum, bowenoid papulosis, condyloma acuminatum, lichen planus, lichen nitidus, milia, angiofibroma, epidermal cyst, calcinosis cutis, granuloma annulare, and sarcoidosis. ${ }^{3,8,12}$

Because syringoma is benign, treatment is not necessary unless there is a cosmetic problem. ${ }^{3,5,7,8,12}$ There is no satisfactory treatment of eruptive penile syringoma. Treatment options include topical tretinoin and adapalene, oral isotretinoin, cryotherapy, microelectrodesiccation with an epilating needle, dermabrasion, $\mathrm{CO}_{2}$ laser, and surgical excision. ${ }^{2,3,7,8,12}$

Adult patients with penile syringoma may be concerned about sexually transmitted diseases due to the appearance of the papules. If cosmesis is not an issue, clinicians should reassure the patient after a biopsy that the lesions are benign and self-limiting without recommending treatment.

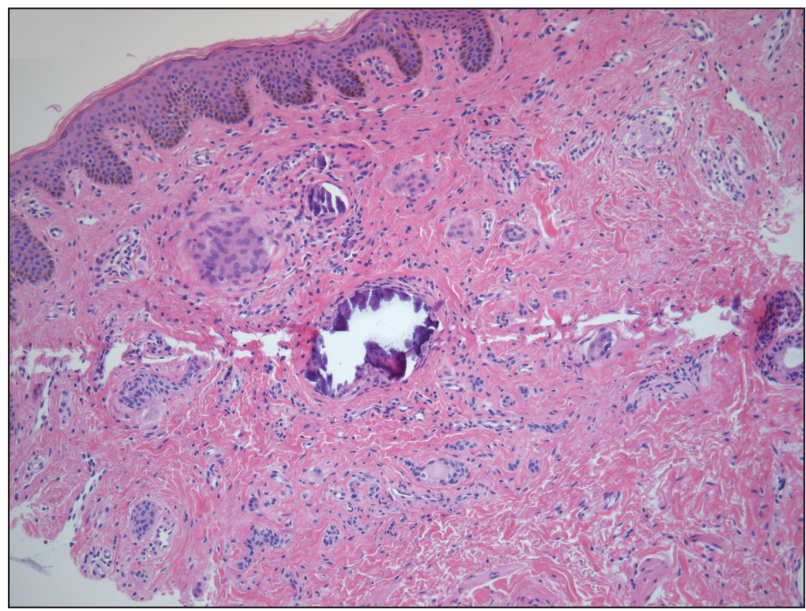

Multiple epithelial cell nests with tadpolelike eccrine ductal structures and several calcium deposits in the dermis (H\&E, original magnification $\times 100$ ).

\section{REFERENCES}

1. Ghanadan A, Khosravi M. Cutaneous syringoma: a clinicopathologic study of 34 new cases and review of the literature. Indian J Dermatol. 2013;58:326

2. Soler-Carrillo J, Estrach T, Mascaro JM. Eruptive syringoma: 27 new cases and review of the literature. J Eur Acad Dermatol Venereol. 2001;15:242-246

3. Baek JO, Jee HJ, Kim TK, et al. Eruptive penile syringomas spreading to the pubic area and lower abdomen. Ann Dermatol. 2013;25:116-118.

4. Pruzan DL, Esterly NB, Prose NS. Eruptive syringoma. Arch Dermatol. 1989;125:1119-1120.

5. Olson JM, Robles DT, Argenyi ZB, et al. Multiple penile syringomas. J Am Acad Dermatol. 2008;59(2 suppl 1):S46-S47.

6. Petersson F, Mjornberg PA, Kazakov DV, et al. Eruptive syringoma of the penis. a report of 2 cases and a review of the literature. Am J Dermatopathol. 2009;31:436-438.

7. Huang C, Wang $\mathrm{W}, \mathrm{Wu}$ B. Multiple brownish papules on the penile shaft. Indian J Dermatol Venereol Leprol. 2011;77:404.

8. Cohen PR, Tschen JA, Rapini RP. Penile syringoma: reports and review of patients with syringoma located on the penis. J Clin Aesthet Dermatol. 2013;6:38-42.

9. Vaca EE, Mundinger GS, Zelken JA, et al. Surgical excision of multiple penile syringomas with scrotal flap reconstruction. Eplasty. 2014;14:E21.

10. Mitkov M, Balagula Y, Taube JM, et al. Plaque-like syringoma with involvement of deep reticular dermis. J Am Acad Dermatol. 2014;71:e206-207.

11. Vaca EE, Mundinger GS, Zelken JA, et al. Surgical excision of multiple penile syringomas with scrotal flap reconstruction. Eplasty. 2014;14:e21.

12. Dhossche JM, Brodell RT, Al HmadaY, et al. Skin-colored papules of the penis. Pediatr Dermatol. 2015;32:145-146.

13. Todd PS, Gordon SC, Rovner RL, et al. Eruptive penile syringomas in an adolescent: novel approach with serial microexcisions and sutureadhesive repair. Pediatr Dermatol. 2016;33:E57-E60. 